\title{
MacGyver y la tecnocreatividad
}

Luke Larraona

Especialista en Creativitat PR, Content \& Social en Tinkle y Social Noise

Admitámoslo: tecnocreatividad es la palabra de moda. No hay agencia moderna, conferencia trendy o máster de renombre que no te casque esa palabra.

Por eso no he venido a explicar lo que es. Ya lo sabemos todos y si no, ya somos mayorcitos para inferir que viene de juntar tecnología y creatividad -si necesitas que hablemos de lo que es alguna de estas dos palabras, te aconsejo dejar esta revista y acercarte con pasión a un diccionario-.

Estoy aquí para hablar del cambio que ha supuesto en la forma de trabajar y para ver sus ventajas y, cómo no, también sus desventajas.

Cuando pienso en creatividad y en los creativos, me gusta imaginar que somos una especie de MacGyvers, en el momento cumbre del capítulo, cuando tiene que salir de un entuerto utilizando sus conocimientos y los materiales que le rodean.

Hace años el entuerto era vender más y los materiales que teníamos podían ir desde una trasera de un bus y unas cuantas fotos de banco de imágenes hasta dos voces, una música de librería y 20 segundos en los que, no sólo debíamos meter una creatividad, sino un chorizo de información con dirección, número de teléfono y nombrando tres veces la marca.

Ahora el entuerto sigue siendo el mismo -aunque se disfrace tras palabras como branding o awareness- $\mathrm{y}$, aunque sigamos utilizando esos materiales denostados -que a los copies nos encantan-, hemos cambiado para trabajar en un escenario lleno de nuevas herramientas que van mutando, evolucionando y desapareciendo a un ritmo que asusta. 
Ahora somos MacGyvers, pero encerrados en un almacén de la NASA o incluso en una nave extraterrestre con un montón de tecnología en un idioma que no conocemos. Empezamos a experimentar con los objetos que caen en nuestras manos: data mining, realidad aumentada, geolocalización, el Internet de las cosas... y nos volvemos locos. Locos porque queremos hacerlo todo y porque estamos ante un mundo de posibilidades:

- Por fin podemos conectar el on y el off de una forma directa dando una experiencia diferenciadora a los usuarios. En nuestra vida ya lo hacemos.

- Podemos conocer al dedillo los gustos y hábitos de la gente. Podemos trackear sus movimientos, descubrir sus anhelos y escucharles. Nos están proveyendo de información constante, sólo hay que estar atentos.

- Eso nos da la posibilidad de adaptar nuestros mensajes al tipo de público. ¿Por qué perder tiempo y dinero en hablar de fútbol a alguien al que lo que le interesa es el cine?

- Dejamos de interrumpir para conversar, entretener y ser muy útiles. Incluso conseguimos que sean ellos los que acudan a nosotros, demandando contenidos interesantes.

- Hacemos acciones con láser, drones voladores, elementos físicos que cambian según lo que los usuarios tuiteen, compartan, comenten... en internet -no sé a ti, pero a mí se me hace la boca agua-.

Pero no es oro todo lo que reluce:

- Normalmente la tecnología precisa de tiempo -y dinero-, algo que no sobra mucho en publicidad. Necesitas tiempo para programar y para que las plataformas acepten las aplicaciones. ¡SÍ, AMIGO! Ahora no sólo es cuestión del ok del cliente, sino el de Facebook o el de la Apple Store.

- La cantidad de tecnologías que aparecen cada día, las políticas de plataformas que cambian cada poco tiempo, las plataformas nuevas que aparecen -y que desaparecen igual de pronto-, etc. hacen que tengas que pasar gran parte de tu tiempo dedicado a estar al día -leyendo descripciones técnicas, foros y blogs, en vez de invertirlo en novelas, cine o comics-.

- Se añade un paso a la cadena de trabajo y otras manos por las que pasan las ideas (a no ser que seas el Leonardo Da Vinci del siglo XXI). Esto exige una explicación clara de todo lo pensado, reuniones e incluso, dejarte en manos de los expertos en tecnología. Una de las preguntas que más hago yo a la parte tecnológica es «¿creéis que esto se puede hacer?» y luego "¿y cómo se hace?». En ocasiones es sí; en otras, sientes que tu cabeza le lleva siglos de ventaja a la tecnología.

- Con tanta novedad y tanto elemento alucinante, a veces perdemos el norte y nos olvidamos de lo importante: tenemos que comunicar algo para con- 
seguir unos objetivos. Dejamos de lado construir un concepto fuerte, bien asentado, sobre el que crear caminos de comunicación y nos quedamos en la anécdota.

Este último punto es el que más me preocupa. Soy la primera que quiere hacer volar un ejército de drones y crear un holograma a tamaño natural de Mocedades en Eurovisión, pero ¿a qué precio? ¿Es justo que las marcas nos paguen la ocurrencia, si ésta no va a construir en su favor?

La tecnología puede darnos muchas portadas, entradas en blogs y compartidos, pero sólo si está ligada a la creatividad, con un concepto y una estrategia coherente, dejará de ser una anécdota y será auténtica publicidad.

Volvamos a MacGyver en esa nave extraterrestre. El hombre se siente abrumado, porque no entiende nada, pero tiene lo importante: El cerebro y las ganas de aprender -no nos engañemos: nadie aprende si no quiere hacerlo-. Todo lo que le rodea son elementos al servicio de la idea que él construya en su cabeza y podrán aportar hasta convertirla en algo maravilloso o deslucirla si no están bien elegidos. Tal vez nuestro héroe tire de smartphone para entender la idiosincrasia de los objetos que le rodean -Google o Yahoo Answers, por ejemplo- , encuentre algún alienígena bondadoso que le explique el funcionamiento y utilidad de cada uno de ellos o se dedique al ensayo y error hasta conseguirlo. Pero una cosa está clara: sin una cabeza pensante, no habrá tecnocreatividad.

\section{Referencia de este artículo}

Larraona, Luke (2014). MacGyver y la tecnocreatividad. En: adComunica. Revista Científica de Estrategias, Tendencias e Innovación en Comunicación, $\mathrm{n}^{\circ} 8$. Castellón: Asociación para el Desarrollo de la Comunicación adComunica, Universidad Complutense de Madrid y Universitat Jaume I, 215-217. DOI: http:// dx.doi.org/10.6035/2174-0992.2014.8.14. 
